\title{
Research on the Critical Response Method in Bilingual Teaching
}

\author{
Hongmei Zhang \\ Department of Biology, Dezhou University \\ Dezhou 253023, Shandong, China \\ Tel: 86-534-898-5840Ｅ-mail: dzxy7678@163.com
}

\begin{abstract}
This paper primarily expounds the critical teaching theory, the concept of critical response teaching method and its actual application. For the first time, the practical application of the critical response teaching method is proposed in the bilingual teaching and a bilingual teaching model in combination with my own teaching experience is worked out.
\end{abstract}

Keywords: Bilingual teaching, Critical teaching idea, Critical response teaching method, Cell biology

Cell biology, as one of the basic and compulsory courses of biology, has attracted more and more attention. With the international development of biotechnology and China's outstanding contribution in the field of biology, cell biology has become an international course. In order to make cell biology teaching in the right orbit of the world, its bilingual education has become inevitable. Currently the necessity and the benefits brought by the teaching practice of cell biology can be seen obviously and distinctly. Thus it is a positive attempt to reform the bilingual teaching method though there are still many problems and challenges in the college teaching reform. In recent years, a lot of articles have been published about the bilingual education, mainly in the exploration of the requirements for teachers, students and the choices of teaching materials in the bilingual teaching process. (Xu, 2007, pp.118-119). All these things are the basic preconditions for bilingual education. But do these conditions lead to a very good teaching result? I am not sure because bilingual education is different from the mother-tongue teaching. In the teaching process there will inevitably be some unexpected difficulties. In order to overcome the difficulties and improve the teaching quality, a teaching concept or philosophy is necessary for it is the theoretic fulcrum of the teaching activities. In addition to the teaching concept, there must be a corresponding teaching method. In this paper, I cite some examples from my bilingual teaching of the cell biology to give an exploration of the critical teaching philosophy and the response teaching method.

\section{The critical teaching concept}

The so-called critical teaching concept (Brookfield, 2006, pp 79-85) is about a set of values and beliefs of guiding the students to produce some questions and exploring the world according to the teaching styles and the teaching purpose. In the core are a series of objectives, on the basis of which, striving direction can be adjusted. I think, it is not enough for a university teacher simply defines himself or herself as an expert or specialist who can imbue the teaching content or some skills into the students in a narrow field. As a matter of fact, another identity of more significance, as a motivation to promote the world change and social development, is deprived of helping the students to shape themselves. With the teaching concept echoes occasionally, teachers will always keep the teaching objective in mind, (it has a broad sense and does not only refer to the teaching purpose of each class.) which helps to determine whether they are moving towards this goal. Each school has a set of educational regulations, which are well planned and arranged at the very beginning of every semester. Changes can be made in every course according to the actual practice. As to how to change, teachers must abide by their own teaching concept and the core of it. Or at least they should know what will be or has been changed is good for the students. The bilingual teaching purpose of the cell biology is to make the students master the basic knowledge and skills of cell biology, shape the way of thinking of biological science so that they can fluently read the English magazines about cell biology and even the English original to be able to know about the forefront of development of cell biology.

\section{Develop the students' way of critical thinking under the guidance of critical concepts}

Developing the way of critical thinking is the basis for all teaching activities. Help should be provided for the students 
to shape an acute critical way of thinking. They should learn to doubt, to question the ultimate solution, to be willing to accept different options, to recognize there are no final solutions for knowledge can be controlled by the scientific and technological development and environment, and to dive into the deep sea of knowledge and pursue the reasons. In the bilingual teaching of the cell biology, when it comes to a certain cell phenomenon, I let my students to adopt what they have learned to design an experiment to find or prove the phenomenon. Then I will tell them how their predecessors did. Finally I let them analyze what are the differences between their experiment and what the predecessors have done, the strong points or the defects. In this way the students have learned to study and make doubt actively, the analytical ability of students has been cultivated and the habit of critical way of thinking has been developed.

\section{Critical response teaching method is adopted based on the critical teaching concept.}

The so-called critical response teaching method (Brookfield, 2006, pp 79-85) means that a clear concept should be owned to guide what will be done, meanwhile, methods should be actively adjusted to attain the best. As a college teacher, it is important to find out why what is being taught is just what should be taught. Of course it is not enough. What is the most important is to imbue them into the students. Therefore, teachers who adopt the critical teaching method on the one hand, are guided by the basic teaching concept and on the other hand, have paid close attention to the study situations of the students and the changing environment, which can not be completely predictable. Critical response teaching method embodies that teachers actively adjust their teaching means, content and methods to meet the class needs and learning styles of students. The teachers are not limited to the predetermined method of teaching. They and their students can work together to improve teaching materials, carry out the examinations and explore some biological phenomena.

Bilingual education is developing and there is no fixed effective teaching model. Since I began my teaching career, I have been learning from other people and trying to find my own method of teaching. And I finally find out that the response teaching method is more suitable. At the very beginning, I drew on the experience of others and thought that the discussion method was a good teaching model for it was not only able to improve the learning motivation of the students, but also help them practice their spoken English. So, in each class, I put forward some themes based on the teaching content and then ask my students to discuss them in English only to find they are always slipping into silence after talking about the superficial content. They find it hard to have a deep discussion. Two weeks later, I conducted a questionnaire and the result showed that my students believed through this approach they could not learn systematic professional knowledge, give expressions in standard English. Thus the teaching effectiveness is not ideal. Later, I adjusted my teaching methods according to the feedback from students. In my solo lecture, I made the knowledge systematic after I discussed with them. After a week of experiment, the feedback from my students showed that they could not understand what I had said or keep up with the pace. It was obvious that the teaching result was not satisfactory and the teaching goal was not reached. During the process, I accidentally found that those students who were good at reading were quicker in response could understand well in listening to what is in English. So I gave them the materials used in the next class and asked them to read loudly after class. If they could not read professional materials, I would let them read technological news. Time and time again, they have had developed a sense of language. They could speak and it would be natural and easy for them to hear and understand those materials about their specialty. In the second year I chose the students majoring in English who had attended biological classes to have my course. Although they had studied some word formation and were familiar with many English words, I still suggested that they should read aloud. In addition, they should also have some discussions. After two years of exploration, I summed up my own teaching method. After class, I make my students read aloud. (They must utter the words out). Then I will give my systematical explanations in class (My students tell me that my explanation is really vital because it is different from their reading. During the explanation, I can put my way of thinking into the knowledge while they only find the points in reading.) Finally, I will let the students discuss some certain themes in English. With the systematic knowledge, they have deeper and deeper discussion and sometimes they can make some remarks on the experiments performed by the predecessors under the limited experimental conditions. During the process, the students do not only develop a sense of the English language, practice their abilities of focus listening and English expression, but also gain expertise in cell biology and cultivate their critical thinking approach. Of course, the teaching method still needs further exploration. In order to gain better result of teaching and learning, I have always insisted that the students fill out questionnaires and keep their study diaries in order to get the feedback in time to adjust my teaching. And the questionnaire mainly includes the followings:

a. One or several things that are most rewarding or the moment that make you feel most excited in learning this week.

b. One or several things that make you feel deeply frustrated or discouraged in learning in this week.

c. What characteristics or behaviors do you think are most helpful for your study?

d. What characteristics or behaviors do you think hinder your study?

e. Is the teaching method suitable for you? If it is appropriate, what progress have you made? If it is not appropriate, what hinders your study and how to adjust it to fit your learning? 
A learning journal is mainly about the recall of what the students have learned in this period and the details written down as following:

a. What makes you most excited in this period and why?

b. What is the most impressive and positive moment you think and what are the influences it gives you?

c. What is the most impressive and negative moment you feel in this period and why?

d. What makes you feel you are ignored in this period and why?

e. Your own feelings and understandings in this period.

After each class, I will sum up the learning journals and adjust some details of my next lecture according to these learning journals in order that the students will gain some in each class. Questionnaire is held once a week to change my fixed behaviors and my teaching method that can not be fit for my students. In short, the implementation of bilingual teaching is a systematic project. It needs the entire educational environment and the cooperation of the teachers and students. Bilingual teaching method needs constant improving. Practical and effective bilingual teaching requires more efforts. The bilingual education of cell biology will certainly be in a good track of development.

\section{References}

Brookfield, Stephen D. (2006.09). The skillful teacher. Technique, Trust and Responsiveness in the Classroom. Jossey-Bass.

$\mathrm{Xu}$, Zhenping. (2007). Considering improving the bilingual education of cell biology. Journal of Peking University (Philosophy and Social Science). 